\title{
Antihyperglycemic effect of the alkaloids extracted from Adiantum capillus in diabetic rats
}

\author{
Professor Kawa F. Dizaye* , Roshna S. Aziz** \\ ${ }^{*}$ College of Medicine, Hawler Medical University, Erbil, Iraq. \\ ${ }^{\star \star}$ College of Medicine, University of Sulaimani, Sulaimani, Iraq. \\ Correspondence: doctorkawa@gmail.com
}

(Ann Coll Med Mosul 2019; 41 (2):148-157).

Received: $16^{\text {th }}$ Feb. 2019; Accepted: $15^{\text {th }}$ May 2019.

\begin{abstract}
Background: Biomedical researches have long sought to develop novel therapies that are more effective, less costly and possess fewer side effects, to treat chronic diseases including diabetes mellitus. Adiantum capillus is among the medicinal plants that have been widely used in traditional medicine and are known to have hypoglycemic effects. This study was designed to find the chemical constituent of Adiantum capillus that exerts the hypoglycemic effect.

Materials and Methods: Fifty-four rats were split into nine groups. Twelve normal rats were included in the first group; six acted as negative controls and six were administered Adiantum capillus water extract. The second group was comprised of 42 streptozotocin-induced diabetic rats sectioned into seven subgroups of six rats. The first subgroup functioned as a positive control. The second subgroup was administered 100 $\mathrm{mg} / \mathrm{kg} / \mathrm{day}$ of Adiantum capillus aqueous extract for 21 days, while the third and the fourth subgroup received $50 \mathrm{mg} / \mathrm{kg} /$ day of metformin and acarbose respectively. The remaining three groups were administered alkaloids ( $4 \mathrm{mg} / \mathrm{kg} /$ day), flavonoids ( $24 \mathrm{mg} / \mathrm{kg} /$ day) and phenolic compounds ( $30 \mathrm{mg} / \mathrm{kg} /$ day) extracted from Adiantum capillus for 21 days. Fasting blood glucose levels, insulin levels, insulin resistance, serum amylase levels, C-peptide levels, liver function and renal function were monitored.

Results: The use of an Adiantum capillus aqueous extract in diabetic rats for 21 days effectively controlled blood glucose levels, elevated amylase level and improved renal and liver function. A significant decrease in blood glucose, AST, ALT, ALP and blood urea levels accompanied by significant increase in the serum amylase of diabetic rats was produced by the alkaloids extracted from Adiantum capillus. However, flavonoids and phenolic compounds did not cause any significant change in blood glucose levels.

Conclusion:lt can be concluded that the alkaloids extracted from Adiantum capillus are the chemical constituent that contributes to the antihyperglycemic effect of the plant.
\end{abstract}

Key words: Adiantum capillus, Diabetes mellitus, Flavonoids, alkaloids, phenolics.

$$
\begin{aligned}
& \text { تأثير القلويدات المستخلصة من كزبرة البئر (Adiantum capillus) } \\
& \text { على خفض مستوى سكر الام في الجرذان المصابة بمرض السكري }
\end{aligned}
$$

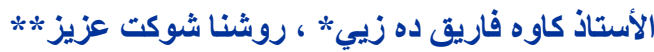

$$
\begin{aligned}
& \text { *قرع الادوية، كلية الطب، جامعة هولير الطبية، اربيل، العراق، ٪* فرع الادويثة، كلية الطب، جامعة السليمانية، السليمانية، العراق }
\end{aligned}
$$

سعت الأبحاث الطبية الحيوية منذ فترة طويلة إلى تطوير علاجات جديدة أكثر فعالية وأقل تكلفة وذات آثار جانبية أقل ، لعلاج الأمر اض المزمنة بما في ذلك مرض السكري. كزبرة البئر هو من بين النباتات الطبية التي تم استخدامها على نطاق واست واسع في في 
الطب التقليدي للحد من ارتفاع السكر في الدم. تم تصميم هذه الدراسة للعثور على المكون الكيميائي لكزبرة البئر الذي يخفض

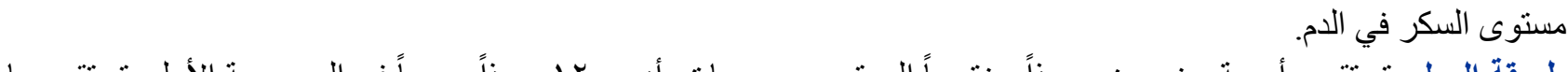
طريقة العمل: تم تقسيم أربعة وخمسين جرذاً مختبرياً إلى تسع مجموعات. أدرج با ال جرذاً صحياً في المجمو عة الأولى تم تقسيمها

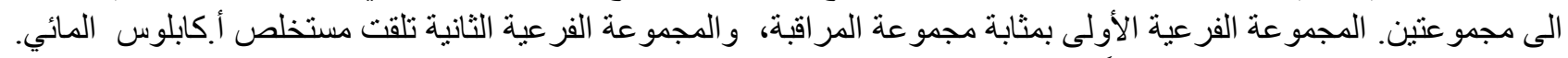

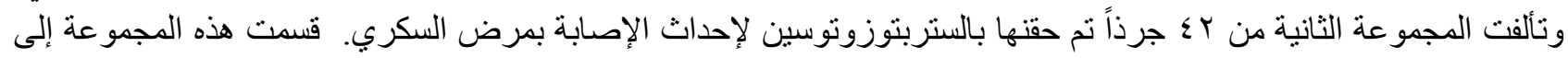

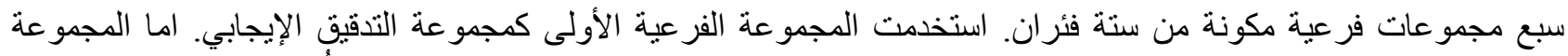

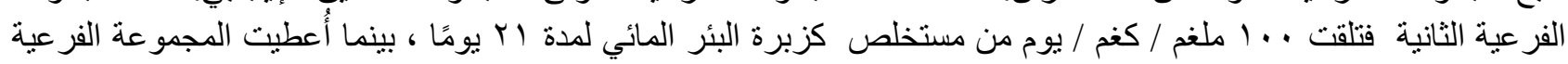

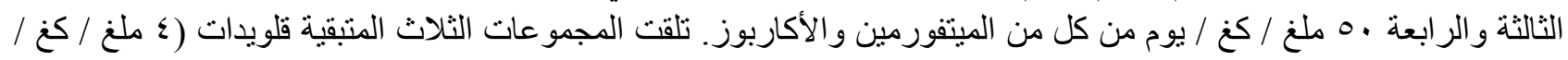

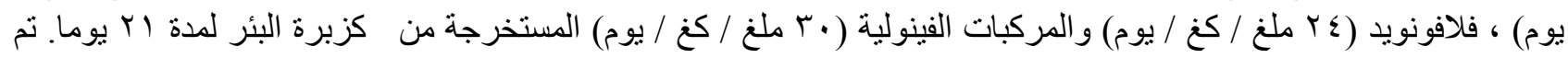

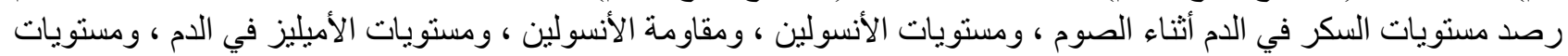

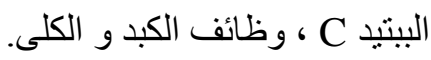

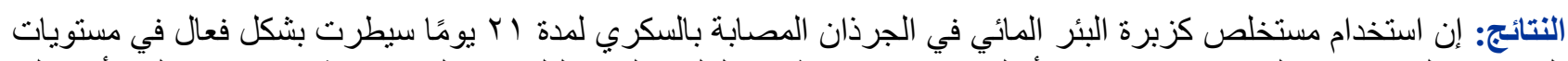

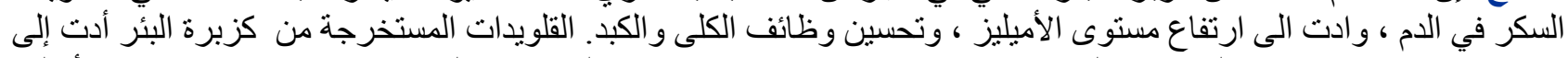

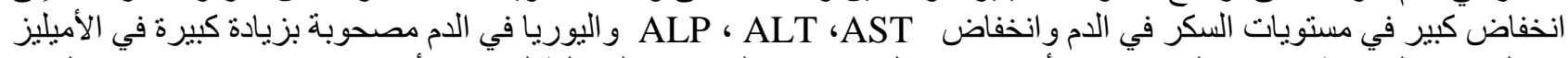

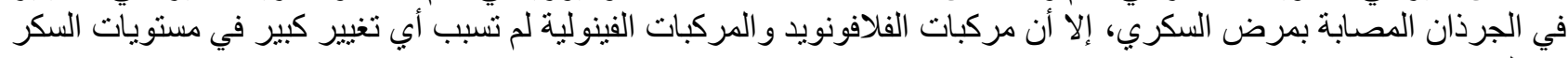

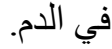
الأستنتاج: يمكن أن نستنتج أن قلويدات المستخرجة من كزبرة البئر هي المكون الكيميائي الذي يساهم في تقليل ارتفاع السكر في

الكلمات المفتاحية: نبات كزبرة البئر ، داء السكر ، الفلافونويد ، القلويات ، الفينول .

\section{INTRODUCTION}

Tr he diabetes mellitus (DM) is an epidemic and the associated complications pose a significant health hazard worldwide. They have contributed significantly to global disability and mortality rates, in addition to increasing the incidence of cardiovascular diseases particularly in individuals with DM and metabolic syndrome ${ }^{1,2}$. Chronic hyperglycemia associated with DM is linked to longstanding impairment, dysfunction and the failure of several organs, including the eyes, blood vessels, kidneys, nerves and heart ${ }^{3}$.

For thousands of years, the herbal medicinal system has been postulated and proven to safeguard patients' health and alleviate diseases and disorders by means of realistic observation and trial and error experimentations ${ }^{4}$.

Medicinal plants play a fundamental role in the development of novel drugs. Several pharmacological activities including the treatment of cancer; immunomodulation; nervous system activation; hepatoprotection and antipyretic, analgesic and antidiabetic activities have been performed by plants and their products ${ }^{5}$.
Despite of the development and mass production of chemically synthesized drugs, paired with a global transformation of healthcare, a considerable portion of the populations of various countries still depends on herbal medicines for primary care needs, in both developing and industrialized countries ${ }^{6}$. About $80 \%$ of the world's population is dependent on the conventional medicine, as estimated by the $\mathrm{WHO}^{7}$.

Diabetes and herbs have a longstanding relationship; many different plants have been used to treat DM in various parts of the world, and many of them have been scientifically proven to be potent antidiabetic agents. Around 400 traditional, plant-based remedies for diabetes have been doccumented; the hypoglycemic impact of some herbal extracts has been verified in human and animal models of type 2 DM, but only a small number of these plants have been evaluated scientifically and medically study their effectiveness ${ }^{8,9}$.

Several herbal medicines have been proposed for the management of DM, In addition to the existing therapeutic options for DM such as insulin 
and oral hypoglycemic agents, which have their own limitations ${ }^{10}$.

Although oral hypoglycemic agents are still the cornerstone of DM management, their adverse side effects and/or high cost leave patients seeking alternative therapies ${ }^{11}$. Identifying and isolating medicinal plant compounds with antidiabetic properties may allow the development of a novel class of antidiabetic drugs ${ }^{12}$.

Adiantum capillus (AC) is a member of the Pteridaceae family; it is one of the most frequently used and widely distributed species in this family. Ethnomedicinally, the genus has been used as tonic and diuretic; it is used in cold therapy, to treat fevers, coughs and bronchial disorders; as a stimulant and a laxative; to treat skin diseases; in spleen, liver and other visceral tumors ${ }^{13,14}$, and in the treatment of jaundice and hepatitis ${ }^{15}$.

Previous studies have suggested that Adiantum capillus aqueous extract (ACAE) has antihyperglycemic effects in rabbits and rats ${ }^{12-16}$, but the exact part of the plant that produce this effect has yet to be identified ${ }^{17}$. Many studies have demonstrated that alkaloids are one of the phytoconstituents of $\mathrm{AC}$ in addition to various classes of triterpenoids and flavonoids ${ }^{7-18}$. Alkaloids are among the plant constituents that have been used as a treatment for many diseases, including DM, along with flavonoids and phenols ${ }^{19}$.

Accordingly, the present study was designed to evaluate the antihyperglycemic effect in normal and diabetic rats of the variety of $A C$ cultivated in Kurdistan of Iraq, as well as some of its constituents, such as flavonoids, alkaloids and phenolics.

\section{MATERIALS AND METHODS}

\section{Plant Material Collection, Authentication and} Preparation of Plant Extracts

Fresh specimen of Adiantum capillus were collected in March of 2018 from the Hawraman Mountains in Sulaimani and were dried in the shade for 10 days. To create the aqueous extract, about one gram of dried coarsely ground plant material was soaked in $20 \mathrm{ml}$ of boiled distilled water in a conical flask for 24 hours. It was then filtered through filter paper and the plant residue was discarded. The extract was refrigerated in a tightly sealed container.
To extract alkaloids, $10 \mathrm{~g}$ of the crude material sample were placed in $400 \mathrm{ml}$ of $10 \%$ acetic acid and $98 \%$ ethanol and macerated for 48 hours at room temperature. The product of the extract was $2.76 \%$. To extract flavonoids, $10 \mathrm{~g}$ of the crude material sample were mixed into $200 \mathrm{ml}$ of highperformance liquid chromatography (HPLC) grade methanol and macerated for 48 hours at room temperature, resulting in an extract yield of $18.4 \%$. Phenolic compound extraction was performed by adding $10 \mathrm{~g}$ of the crude material sample to 500 $\mathrm{ml}$ of $70 \%$ ethanol and macerating the mixture for 72 hours at room temperature. The extract yield was $23 \%$. According to these exctracted yields the doses of the alkaloids, flavonoids and phenolic compounds have been calculated.

\section{Animals}

Healthy albino female wistar strain rats weighing 190-240 $\mathrm{g}$ were used in this research. Throughout the experimental period, the animals were accommodated in colony cages at the animal house at the College of Veterinary Sciences, University of Sulaimani for 1-2 weeks prior to initiating the experimentation. They were kept under standard laboratory conditions, which consist of a temperature range of $\left(27 \pm 2^{\circ} \mathrm{C}\right)$, with light and dark cycles lasting 12 hours. The animals were supplied with food (pellets) and water as desired. Approval was granted by the Ethical Committee of the College of Medicine at the University of Sulaimani (Permit Number: 7/5/927).

\section{Induction of Diabetes Mellitus in Rats}

Diabetes was induced by a single dose intraperitoneal shot of $40 \mathrm{mg} / \mathrm{kg}$ of freshly prepared streptozotocin (STZ) solution in a citrate buffer $(0.1$ $\mathrm{M}$, $\mathrm{pH}$. of 4.5), delivered to rats that had fasted overnight.

Blood samples were collected from the tail vein after three days by pricking the tail, following at least 12 hours of fasting. Fasting blood glucose (FBG) levels were measured using a glucometer. The animals with obvious hyperglycemia (FBG > 200 or $250 \mathrm{mg} / \mathrm{dl}$ ) were included in the study ${ }^{20,21}$.

This study was conducted using nine groups of six rats. They were administered oral treatments as follows:

Group I: Normal rats served as a negative control; they were administered only the vehicle (distilled water) for 21 days. 
Group II: Normal rats treated with ACAE (100 $\mathrm{mg} / \mathrm{kg} /$ day) for 21 days.

Group III: Diabetic rats served as positive control; they were given only the vehicle (distilled water) for 21 days.

Group IV: Diabetic rats treated with an aqueous solution of Metformin (50 mg/kg/day) for 21 days.

Group V: Diabetic rats treated with an aqueous solution of Acarbose (50 mg/kg/day) for 21 days Group VI: Diabetic rats treated with ACAE (100 $\mathrm{mg} / \mathrm{kg} /$ day) for 21 days.

Group VII: Diabetic rats treated with alkaloid extracted from AC (4 mg/kg/day) for 21 days.

Group VIII: Diabetic rats treated with flavonoid extracted from AC (24 mg/kg/day) for 21 days.

Group IX: Diabetic rats treated with phenolic compounds extracted from AC (30 mg/kg/day) for 21 days.

Following 21 days of treatment, rats were fasted overnight. Blood samples were collected the following day. The first step in this procedure was to anaesthetize the rats with a combination of xylazine $(5 \mathrm{mg} / \mathrm{kg})$ and ketamine $(35 \mathrm{mg} / \mathrm{kg})$; then a cardiac puncture was performed using a sterile disposable plastic syringe and the blood samples were stored in definite numerically labeled blood tubes $^{9}$. These blood samples were used to determine levels of FBG, insulin level, serum amylase, $C$ peptide, blood urea, serum creatinin, aspartate aminotransferase (AST), alanine aminotransferase (ALT) and alkaline phosphatase (ALP).

The concentration of insulin and $C$ peptide in serum samples was estimated using EnzymeLinked Immunoabsorbent Assay (ELISA) method. Quantitative determination of serum amylase, serum creatinine, serum urea, AST, ALT and ALP was carried on Roche/Hitachi cobas c 311 systems, according to to the manufacturer's conditions.

Blood samples were collected from the tail vein following a regular schedule. FBG levels were assessed on days 0,10 and 21 using the glucose oxidase, and the readings were processed using AutoAnalyzer.

Insulin resistance (IR) was assessed using homeostasis model assessment of insulin resistance (HOMA-IR), which is calculated from fasting serum insulin (FSI) and fasting $\mathrm{FBG}$ as in the following formula ${ }^{22}$.

HOMA-IR $=\mathrm{FSI}(\mu \mathrm{U} / \mathrm{ml}) \times \mathrm{FBG}(\mathrm{mmol} / \mathrm{L}) / 22.5$

\section{Statistical Analysis}

Data were analyzed statistically using Statistical Package for Social Sciences(SPSS) Version 24.0 for Windows. All the data were expressed as a mean \pm SE. Comparisons between groups were performed using Duncan's test and the Student's ttest. A p-value of 0.05 or less was regarded as statistically significant.

\section{RESULTS}

Effects of aqueous extract $(100 \mathrm{mg} / \mathrm{kg} /$ day) of Adiantum capillus on, insulin resistance and levels of fasting blood glucose, insulin, C-peptide and amylase in normal rats

The results of this study indicate a decline in insulin resistance and the levels of FBG, insulin, Cpeptide and amylase in normal rats following daily oral administration of ACAE as compared with the control group. However, these changes were statistically not significant. Table 1

Table 1: Effects of aqueous extract $(100 \mathrm{mg} / \mathrm{kg} / \mathrm{day})$ of Adiantum capillus on fasting blood glucose, serum insulin, C-peptide, insulin resistance and amylase in normal rats $(n=12)$.

\begin{tabular}{|c|c|c|c|}
\hline Parameter & $\begin{array}{c}\text { Normal } \\
\text { Rats }\end{array}$ & $\begin{array}{l}\text { Normal } \\
\text { Rats } \\
\text { Treated } \\
\text { with /AC }\end{array}$ & $\begin{array}{c}\mathbf{P} \\
\text { value }\end{array}$ \\
\hline $\begin{array}{l}\text { Blood Glucose } \\
\text { (mg/dl) }\end{array}$ & $90.8 \pm 4.2$ & $86.7 \pm 1.6$ & 0.34 \\
\hline Insulin (uU/ml) & $14.4 \pm 2$ & $12 \pm 0.9$ & 0.299 \\
\hline $\begin{array}{l}\text { Insulin } \\
\text { resistance }\end{array}$ & $3.3 \pm 0.5$ & $2.6 \pm 0.5$ & 0.26 \\
\hline $\begin{array}{c}\text { C peptide } \\
(\mathrm{ng} / \mathrm{ml})\end{array}$ & $1.9 \pm 0.3$ & $2.1 \pm 0.2$ & 0.74 \\
\hline Amylase (U/L) & $\begin{array}{c}1264.7 \pm \\
73.8\end{array}$ & $1108 \pm 45.5$ & 0.099 \\
\hline
\end{tabular}

Effects of aqueous extract $(100 \mathrm{mg} / \mathrm{kg} / \mathrm{day})$ of Adiantum capillus on blood urea, serum creatinine, AST, ALT and ALP levels in normal rats.

The data reveal a significant decrease in serum creatinine and AST levels in the normal group 
administered daily oral doses of ACAE as compared with the control group. This was accompanied by a non-significant increase in blood urea and ALT levels and a non-significant decrease in ALP levels in the normal group treated with $A C A E$ as compared with the control group. Table 2 .

Table 2: Effects of aqueous extract $(100 \mathrm{mg} / \mathrm{kg} / \mathrm{day})$ of Adiantum capillus on blood urea, serum creatinine, AST, ALT and ALP levels in normal rats $(n=12)$.

\begin{tabular}{|c|c|c|c|}
\hline Parameter & $\begin{array}{l}\text { Normal } \\
\text { Rats }\end{array}$ & $\begin{array}{c}\text { Normal } \\
\text { Rats } \\
\text { treated } \\
\text { with /AC }\end{array}$ & $\begin{array}{c}\mathbf{P} \\
\text { Value }\end{array}$ \\
\hline $\begin{array}{l}\text { Blood urea } \\
\text { (mg/dl) }\end{array}$ & $36 \pm 1.8$ & $40 \pm 2.1$ & 0.177 \\
\hline $\begin{array}{c}\text { Serum creatinine } \\
(\mathrm{mg} / \mathrm{dl})\end{array}$ & $\begin{array}{c}0.45 \\
\pm 0.04\end{array}$ & $0.3 \pm 0$ & $0.006^{*}$ \\
\hline $\begin{array}{l}\text { AST } \\
(\mathrm{U} / \mathrm{L})\end{array}$ & $\begin{array}{c}125.5 \pm \\
4.9\end{array}$ & $\begin{array}{c}118.5 \pm \\
6.6\end{array}$ & $0.039^{*}$ \\
\hline $\begin{array}{l}\text { ALT } \\
(\mathrm{U} / \mathrm{L})\end{array}$ & $\begin{array}{c}34.5 \pm \\
2.7\end{array}$ & $42.8 \pm 2.2$ & 0.414 \\
\hline $\begin{array}{l}\text { ALP } \\
\text { (U/L) }\end{array}$ & $\begin{array}{c}120.5 \pm \\
5.9\end{array}$ & $118 \pm 7.6$ & 0.867 \\
\hline
\end{tabular}

- Significant differences at $p \leq 0.05$
Effects of aqueous extract of Adiantum capillus, Metformin and Acarbose on blood glucose and insulin levels in diabetic rats

Intraperitonial injection with $40 \mathrm{mg} / \mathrm{kg}$ of STZ produced a significant increase in the blood glucose levels of normal rats, accompanied by a significant decrease in insulin levels. Daily oral administration of ACAE for 21 days significantly reduced the FBG levels of diabetic rats, whereas oral administration of Metformin and Acarbose for 21 days resulted in a non-significant reduction in their FBG levels. Oral administration of ACAE to diabetic rats also brought about a non-significant increase in insulin levels as compared with rats from the diabetic control group, as well as the diabetic groups treated with metformin and acarbose. (Table 3)

Table 3: Effects of aqueous extract $(100 \mathrm{mg} / \mathrm{kg} / \mathrm{day})$ of Adiantum capillus, Metformin $(100 \mathrm{mg} / \mathrm{kg})$ and Acarbose $(60 \mathrm{mg} / \mathrm{kg})$ on blood glucose and insulin levels in diabetic rats.

\begin{tabular}{|c|c|c|c|c|c|}
\hline Parameter & Normal rats & Diabetic rats & $\begin{array}{l}\text { Diabetic rats } \\
\text { treated with AC }\end{array}$ & $\begin{array}{l}\text { Diabetic rats treated } \\
\text { with metformin }\end{array}$ & $\begin{array}{c}\text { Diabetic rats } \\
\text { treated with } \\
\text { acarbose }\end{array}$ \\
\hline $\begin{array}{l}\text { Blood glucose } \\
\text { (mg/dl) }\end{array}$ & $\begin{array}{c}83.8 \pm 3.2 \\
a\end{array}$ & $\begin{array}{c}399.3 \pm 17.8 \\
b\end{array}$ & $\begin{array}{c}119.7 \pm 14.2 \text { * } \\
\mathrm{a}\end{array}$ & $\begin{array}{c}301.7 \pm 44.7^{* *} \\
b\end{array}$ & $\begin{array}{c}333.3 \pm 57.8^{* *} \\
b\end{array}$ \\
\hline Insulin (uU/ml) & $\begin{array}{c}11.7 \pm 0.7 \\
a \\
\end{array}$ & $\begin{array}{c}0.6 \pm 0.2 * * \\
b\end{array}$ & $\begin{array}{c}1.4 \pm 0.05^{* *} \\
b\end{array}$ & $\begin{array}{c}1.3 \pm 0.03^{* *} \\
b\end{array}$ & $\begin{array}{c}1.3 \pm 0.03 * * \\
b\end{array}$ \\
\hline
\end{tabular}

* $p<0.001$ when compared with the Diabetic rats

${ }^{* *} p<0.001$ when compared with the control

Different letters indicate significant differences at $\mathrm{P}<0.05$.

Effects of aqueous extract of Adiantum capillus on levels of amylase, blood urea, serum creatinine, AST, ALT and ALP in diabetic rats

A significant increase in amylase levels in diabetic rats was recorded following 21 days of oral treatment with ACAE, as compared with the control group. Moreover, the ACAE-treated group presented a significant decrease in blood urea, AST, ALT and ALP levels as compared with the non-treated group. On the other hand there was a non-significant decrease in serum creatinine levels in the ACAE-treated diabetic rats as compared with the control group. Table 4 
Table 4: Effects of aqueous extract (100mg/kg/day) of Adiantum capillus on levels of amylase, blood urea, serum creatinin, AST, ALT and ALP in diabetic rats.

\begin{tabular}{|c|c|c|c|}
\hline Parameter & Normal rats & Diabetic rats & $\begin{array}{c}\text { Diabetic rats treated with } \\
\text { AC }\end{array}$ \\
\hline Amylase (U/L) & $\begin{array}{c}1264.7 \pm 73.8 \\
a\end{array}$ & $\begin{array}{c}392.7 \pm 29.8 \\
C\end{array}$ & $\begin{array}{c}737.5 \pm 62.4 \\
b\end{array}$ \\
\hline Blood urea (mg/dl) & $\begin{array}{c}36 \pm 1.7 \\
a\end{array}$ & $\begin{array}{c}103.3 \pm 16 \\
b\end{array}$ & $\begin{array}{c}56 \pm 6 \\
a\end{array}$ \\
\hline Serum creatinin (mg/dl) & $\begin{array}{c}0.45 \pm 0.04 \\
a\end{array}$ & $\begin{array}{c}0.46 \pm 0.04 \\
a\end{array}$ & $\begin{array}{c}0.38 \pm 0.03 \\
a\end{array}$ \\
\hline AST (U/L) & $\begin{array}{c}125.5 \pm 4.9 \\
a\end{array}$ & $\begin{array}{c}212.3 \pm 12.1 \\
b\end{array}$ & $\begin{array}{c}121.5 \pm 13.4 \\
a\end{array}$ \\
\hline ALT (U/L) & $\begin{array}{c}34.5 \pm 2.7 \\
a\end{array}$ & $\begin{array}{c}91.8 \pm 5.4 \\
b\end{array}$ & $\begin{array}{c}45.1 \pm 3.6 \\
a\end{array}$ \\
\hline $\operatorname{ALP}(\mathrm{U} / \mathrm{L})$ & $\begin{array}{c}120.5 \pm 6 \\
a\end{array}$ & $\begin{array}{c}404 \pm 92.2 \\
b\end{array}$ & $\begin{array}{c}163.7 \pm 14.4 \\
a\end{array}$ \\
\hline
\end{tabular}

Different letters indicate significant differences at $P<0.05$.

Blood Glucose in diabetic rats treated with flavonoids, alkaloids and phenolic compounds extracted from AC

Following 21 days of treatment each with of ACAE, flavonoids, alkaloids and phenolic compounds extracted from AC, a significant decrease was observed in the blood glucose levels of diabetic rats in the group treated with alkaloids. However, flavonoids and phenolic compounds did not cause any significant change in blood glucose levels. Figure 1

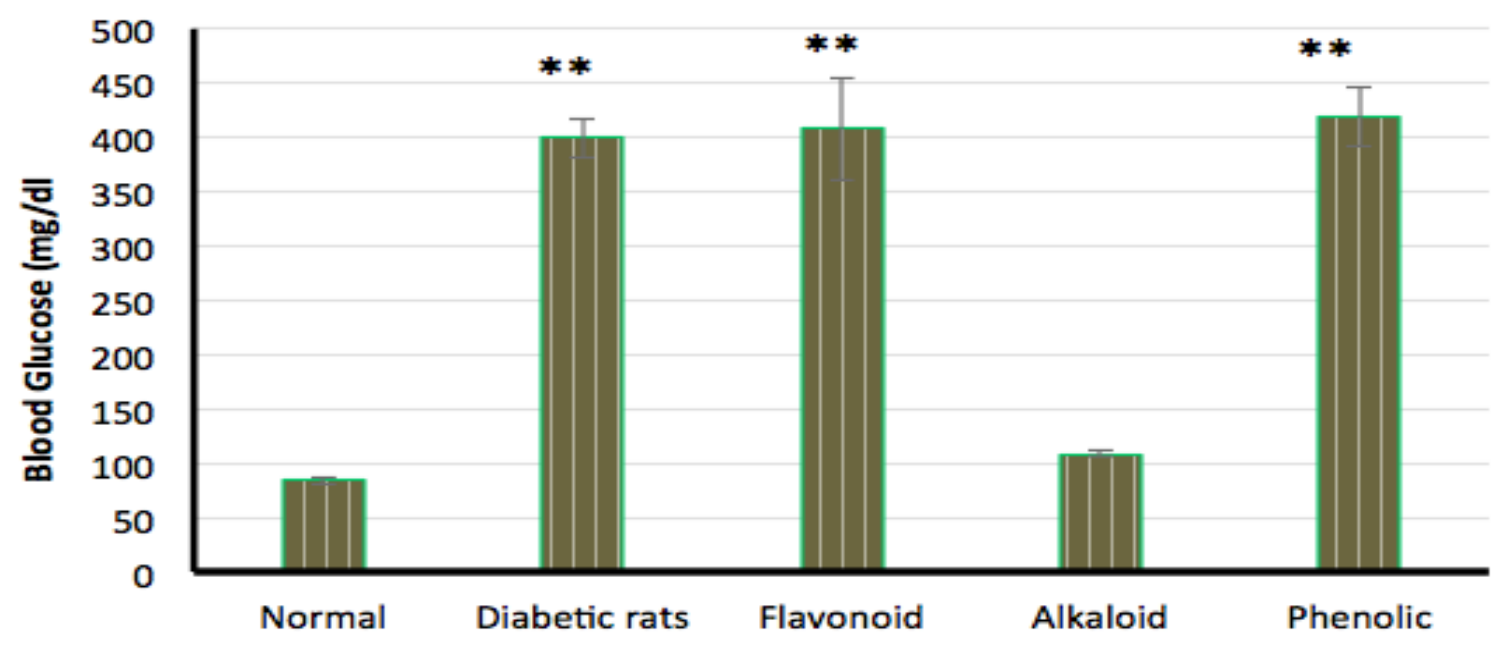

Figure 1: Blood Glucose in diabetic rats treated with flavonoid, alkaloid and phenolic compounds extracted from $A C$

${ }^{* *} P<0.001$ when compared with the control 
Effects of alkaloids extracted from Adiantum capillus, on levels of blood glucose, insulin, amylase, AST, ALT, ALP, blood urea and serum creatinin in diabetic rats

When administered to diabetic rats, alkaloids extracted from AC produced a significant decrease in blood urea, blood glucose, AST, ALT and ALP levels, as compared with the untreated diabetic group. Furthermore, alkaloids given to diabetic rats triggered a significant increase in serum amylase levels as compared with results in untreated diabetic rats. However, insulin levels in diabetic rats treated with alkaloids exhibited a non-significant increase in comparison with untreated diabetic rats. Table 5 .

Table 5: Effects of alkaloid extracted from Adiantum capillus on levels of blood glucose, insulin, amylase, AST, ALT, ALP, blood urea and serum creatinin in diabetic rats .

\begin{tabular}{|c|c|c|c|}
\hline Parameters & Normal rats & Diabetic non treated rats & $\begin{array}{c}\text { Diabetic rats treated with } \\
\text { alkaloid }\end{array}$ \\
\hline Blood glucose (mg/dl) & $\begin{array}{c}83.8 \pm 3.2 \\
a\end{array}$ & $\begin{array}{c}399.3 \pm 17.8 \\
b\end{array}$ & $\begin{array}{c}108.7 \pm 2.3 \\
a\end{array}$ \\
\hline Insulin (uU/ml) & $\begin{array}{c}11.7 \pm 0.7 \\
a\end{array}$ & $\begin{array}{c}0.6 \pm 0.2 \\
b\end{array}$ & $\begin{array}{c}1.4 \pm 0.08 \\
b\end{array}$ \\
\hline $\begin{array}{l}\text { Amylase } \\
\text { (U/L) }\end{array}$ & $\begin{array}{c}1264.7 \pm 73.8 \\
b\end{array}$ & $\begin{array}{c}392.7 \pm 29.8 \\
a\end{array}$ & $\begin{array}{c}1515.2 \pm 11.6 \\
c\end{array}$ \\
\hline $\begin{array}{l}\text { AST } \\
\text { (U/L) }\end{array}$ & $\begin{array}{c}125.5 \pm 4.9 \\
\mathrm{a}\end{array}$ & $\begin{array}{c}212.3 \pm 12.1 \\
b\end{array}$ & $\begin{array}{c}144.2 \pm 11.2 \\
a\end{array}$ \\
\hline $\begin{array}{l}\text { ALT } \\
(\mathrm{U} / \mathrm{L})\end{array}$ & $\begin{array}{c}34.5 \pm 2.7 \\
a\end{array}$ & $\begin{array}{c}91.8 \pm 5.4 \\
b\end{array}$ & $\begin{array}{c}21.9 \pm 0.2 \\
a\end{array}$ \\
\hline $\begin{array}{l}\text { ALP } \\
(\mathrm{U} / \mathrm{L})\end{array}$ & $\begin{array}{c}120.5 \pm 6 \\
a\end{array}$ & $\begin{array}{c}404 \pm \frac{92.2}{b} \\
\text { a }\end{array}$ & $\begin{array}{c}119.8 \pm 13.7 \\
a\end{array}$ \\
\hline Blood urea (mg/dl) & $\begin{array}{c}36 \pm 1.7 \\
\mathrm{a}\end{array}$ & $\begin{array}{c}103.3 \pm 16 \\
b\end{array}$ & $\begin{array}{c}41 \pm 2.2 \\
a\end{array}$ \\
\hline Serum creatinin (mg/dl) & $\begin{array}{c}0.45 \pm 0.04 \\
a\end{array}$ & $\begin{array}{c}0.46 \pm 0.04 \\
a\end{array}$ & $\begin{array}{c}0.4 \pm 0.04 \\
a\end{array}$ \\
\hline
\end{tabular}

Different letters indicate significant differences at $\mathrm{P}<0.05$.

\section{DISCUSSION}

Plants have been used in various medicinal systems for the treatment of many diseases, including $\mathrm{DM}^{23}$. Adiantum capillus is among the plants traditionally used for the treatment of several chronic diseases, and studies regarding its application for DM and renal disease support this theory.

Type $1 \mathrm{DM}$ is the result of autoimmune destruction of pancreatic $\beta$-cells, which renders patients completely dependent on exogenous insulin $^{24}$. In this study, STZ was used to induce a model of type $1 \mathrm{DM}$ in rats ${ }^{25}$.

Although existing research has not sufficiently recognized the impact of and mechanism behind most plant compounds in the treatment of DM, they may work by improving insulin sensitivity, influencing intestinal absorption of glucose, influencing metabolic insulin-dependent processes, enhancing the antioxidant effects of these processes, and stimulating GLUT4 translocation $^{19-26}$.
Streptozotocine is a highly selective pancreatic islet $\beta$-cell cytotoxic agent that induces diabetes through the destruction of pancreatic $\beta$-cells and subsequent insulin deficiency. In the current study, $40-\mathrm{mg} / \mathrm{kg}$ dose of STZ were injected intraperitonially, provoking a significant increase in blood glucose levels accompanied by a significant drop in insulin levels in the rats as compared to those in the control group. This effect has also been reported in other studies ${ }^{9-21}$.

The results of the present study demonstrate that the daily oral administration of ACAE produced a non significant decline in the blood glucose levels in normal rats This finding is in consistent with the results of other studies on the hypoglycemic effects of $A C^{12-19}$. However, regular doses of ACAE for 21 days effectively controlled blood glucose levels in STZ-induced diabetic rats. Likewise, a significant decrease in blood glucose levels was observed in diabetic rats treated with alkaloids extracted from AC for 21 days, indicating that alkaloids in $\mathrm{AC}$ are the constituent 
responsible for its hypoglycemic effect. The glucose lowering effect of 21-day treatment with metformin and acarbose in diabetic rats was notably inferior to the effect of ACAE.

$A$ recent study performed using natural alkaloids it has been suggested that certain alkaloids have the ability to mediate the insulin-signal transduction pathway, reversing molecular defects that causing glucose intolerance and insulin resistance and reducing DM complications, both in-vitro and in-vivo ${ }^{27}$.

The hypoglycemic impact of ACAE can be linked to the existence of insulin-like substances in the plant that stimulate the regeneration and reactivation of $\beta$-cells, which produce more insulin. This is confirmed by the results of a study performed on the histological effects of $A C$ on diabetic rats, it was found that the number of pancreatic $\beta$-cells increase following treatment with AC. Moreover, researchers observed the recovery of partially destroyed $\beta$-cells and the initiation of $\beta$-cell proliferation and regeneration ${ }^{12}$. Some studies have also mentioned that $A C$ chemical constituents can inhibit essential gastrointestinal enzymes involved in carbohydrate digestion and absorption ${ }^{1}$.

AC has been recognized to play an important role in activating the nuclear receptors known as peroxisome proliferator-activated receptors (PPAR), which play a vital role in the homeostasis of glucose and lipids. Upon activation, PPAR primarily functions as a transcription factor, which after binding with the corresponding response elements on the DNA, boosts the expression of primary metabolism genes, resulting in the production of membranous glucose transporters (GLUT). This promotes cellular adaptation of energy consumption to the available nutrient supply ${ }^{28}$.

The data produced in this study demonstrated a significant decrease in serum amylase levels in untreated diabetic rats as compared with control rats. This might be linked to an interruption of insulin activity caused by a lack or absence of insulin or by insulin resistance, as insulin naturally exerts a trophic and stimulant effect on pancreatic acinar cells which secret amylase ${ }^{29-32}$. It may also be caused by a decrease in calcium concentration in the pancreatic acinar cells, as calcium, along with insulin and magnesium, triggers the synthesis and exocytosis of amylase from the acinar cells ${ }^{33}$. However following daily administration of ACAE and alkaloid extracted from AC for 21 days, a significant increase in serum amylase was documented in treated rats as compared with diabetic untreated rats. This observation is consistent with Sultan et al (2013) who suggest that this surge in amylase levels following the application of ACAE might indicate the existence of insulin-like substances in the plant. These substances stimulate the production of insulin by the $\beta$-cells and stimulate pancreatic exocrine function to secrete amylase ${ }^{12}$.

Moreover a remarkable reduction in serum creatinin levels was documented in normal rats treated with $\mathrm{ACAE}$, as compared with untreated rats. This was also reported by other researchers also $^{34}$. The decrease in serum creatinin can be explained by an increase in GFR ${ }^{35}$. Furthermore, a significant reduction in of blood urea levels was detected in diabetic rats treated with ACAE as compared with the untreated diabetic rats. This finding is consistence with another study ${ }^{12}$, which suggests that this effect might be caused by the plant's ability to treat renal dysfunction and that it is an obvious sign of improvement in renal function of diabetic rats.

In diabetic rats treated with ACAE, a significant decline was observed in AST, ALT and ALP levels. This phenomenon indicates an improvement in liver function and demonstrate the plant's ability to repair liver damage caused by $\mathrm{DM}^{12}$. Similarly, the alkaloid extract produced a significant decrease in AST, ALT and ALP levels, indicating that the alkaloids present in $A C$ are responsible for the plant's healing impact on liver damages induced by the diabetes.

\section{CONCLUSION}

The results of the present study demonstrate that Adiantum capillus has retains hypoglycemic properties; specifically, it identifies alkaloids present in $\mathrm{AC}$ as the chemical constituent responsible for this hypoglycemic effect. The mechanism behind this effect may be an increase in insulin sensitivity caused by decreased glycogenolysis, which enhances the transport of blood glucose to peripheral tissues. Further studies are necessary to clarify the specific mechanism in play. Histopathological and adverse 
effect studies of the alkaloids extracted from $A C$ in diabetic rats are recommended.

\section{Acknowledgements}

The authors express their gratitude to Assistant Professor Dr. Hoshyar Abdulla Azeez, The Dean of College of Pharmacy; University of Sulaimani for his kind support. We are highly thankful to Mrs. Shler Akram Faqe for her valuable participation through out this work.

\section{Conflict of Interest}

The authors report no conflicts of interest in this work.

\section{Financial Support}

The authors state that no financial support was received for this work.

\section{Ethics Statement}

The study procedures have been carried out in accordance with the international guidelines of experiments on animals reported elsewhere, and agreement was obtained from the Ethical Committee of the College of Medicine at the University of Sulaimani (Permit Number: 7/5/927).

\section{REFERENCES}

1. Kasabri V, Al-Hallaq EK, Bustanji YK, AbdulRazzak KK, Abaza IF, Afifi FU. Antiobesity and antihyperglycaemic effects of adiantum capillusveneris extracts: In vitro and in vivo evaluations. Pharm Biol [Internet]. 2017;55(1):164-72. Available from: http://dx.doi.org/10.1080/13880209.2016.12335 67

2. Zheng Y, Ley SH, Hu FB. Global aetiology and epidemiology of type 2 diabetes mellitus and its complications. Nat Rev Endocrinol [Internet]. 2018;14(2):88-98. Available from: http://dx.doi.org/10.1038/nrendo.2017.151

3. Ray KK, Seshasai SRK, Wijesuriya S, Sivakumaran $R$, Nethercott $S$, Preiss $D$, et al. Effect of intensive control of glucose on cardiovascular outcomes and death in patients with diabetes mellitus: a meta-analysis of randomised controlled trials. Lancet [Internet]. 2009;373(9677):1765-72. Available from: http://dx.doi.org/10.1016/S01406736(09)60697-8

4. Karunamoorthi K, Jegajeevanram K, Vijayalakshmi J, Mengistie E. Traditional Medicinal Plants: A Source of Phytotherapeutic Modality in Resource-Constrained Health Care Settings. J Evidence-Based Complement Altern Med. 2013;18(1):67-74.
5. Singh S, Sedha S. Medicinal Plants and Their Pharmacological Aspects. 2018;1(4):156-70.

6. Suchacz B, Wesolowski M. The analysis of heavy metals content in herbal infusions. Cent Eur J Med. 2012;7(4):457-64.

7. Ishaq MS, Hussain MM, Siddique Afridi M, Ali G, Khattak M, Ahmad S, et al. In Vitro Phytochemical, Antibacterial, and Antifungal Activities of Leaf, Stem, and Root Extracts of Adiantum capillus veneris . Sci World J. 2014;2014:1-7.

8. Modak M, Dixit P, Londhe J, Ghaskadbi S, Paul T, Devasagayam A. Serial Review Indian Herbs and Herbal Drugs Used for the Treatment of Diabetes. J Clin Biochem Nutr [Internet]. 2007 [cited 2018 Feb 21];40:163-73. Available from: https://www.ncbi.nlm.nih.gov/pmc/articles/PMC2 275761/pdf/jcbn-40-163.pdf

9. Dizaye K, Othman NN. Antihyperglycemic effects of Trigonella Foenum graecum seeds in diabetic Rats Kawa Dizaye *. In: The First Scientific Conference of the College of Medicine/Hawler Medical University On Thursday and Friday, 22nd - 23rd December, 2016. 2018. p. 27-39.

10.Ranjan V, Vats M, Gupta N, Sardana S. Antidiabetic potential of whole plant of Adiantum capillus veneris linn. in streptozotocin induced diabetic rats. Int $J$ Pharm Clin Res. 2014;6(4):341-7.

11.Singh $P$, Mishra A, Singh $P$, Goswami S, Singh A. Diabetes mellitus and use of medicinal plants for its treatment. Indian $\mathrm{J}$ Resaerch Pharm Biotechnol. 2015;3(5):351-7.

12.Sultan AH, Dizaye KF, Hiwa B. B. Histological, Immunocytochemical and Biochemical Study of the Effect of Adiantum Capillus on Alloxan Induced Diabetic Rats. Middle East J Intern Med [Internet]. 2012 Jan [cited 2018 Feb 21];5(1):3-12. Available from: http://platform.almanhal.com/CrossRef/Preview/ ?ID $=2-17583$

13.Singh $M$, Singh $N$, Khare $P B$, Rawat AKS. Antimicrobial activity of some important Adiantum species used traditionally in indigenous systems of medicine. J Ethnopharmacol. 2008;115(2):327-9.

14.Dehdari S, Hajimehdipoor H. Medicinal properties of adiantum capillus-veneris linn. In traditional medicine and modern phytotherapy: A review article. Iran $J$ Public Health. 2018;47(2):188-97.

15.Abbasi AM, Khan MA, Ahmad M, Zafar M, Khan $\mathrm{H}$, Muhammad N, et al. Medicinal plants used for the treatment of jaundice and hepatitis based on socio-economic documentation. African J Biotechnol. 2009;8(8):1643-50.

16.Dizaye K, Qader G, Mahwi T. Hypoglycemic , 
antihistaminic and diuretic effects of aqueous extract of Adiantum capillus. Irq $\mathrm{J}$ pharm. 2011;11(1):1-10.

17.Wani M, Shah M, Naqshi A. Medicinal ferns of Kashmir, India. Int J Bioassays. 2016;5(07):4677.

18. Gaikwad-Samdani K, Rajurkar NS, Gaikwad $\mathrm{K}$. Evaluation of phytochemicals, antioxidant activity and elemental content of Adiantum capillus veneris leaves. Artic J Chem Pharm Res J Chem Pharm Res [Internet]. 2012 [cited 2018 Feb 15];4(1):365-74. Available from: www.jocpr.com

19. Esmail A and A. Medicinal plants with antidiabetic effects ( part 2 ): plant based review. IOSR J Pharm. 2016;6(7):49-61.

20.Elberry AA, Harraz FM, Ghareib SA, Gabr SA, Nagy AA, Abdel-Sattar E. Methanolic extract of Marrubium vulgare ameliorates hyperglycemia and dyslipidemia in streptozotocin-induced diabetic rats. Int $\mathrm{J}$ Diabetes Mellit [Internet]. 2015;3(1):37-44. Available from: http://dx.doi.org/10.1016/j.ijdm.2011.01.004

21.Furman BL. Streptozotocin-Induced Diabetic Models in Mice and Rats. Curr Protoc Pharmacol. 2015;70(September):5.47.15.47.20.

22. Matthews DR, Hosker JP, Rudenski AS, Naylor BA, Treacher DF, Turner RC. Homeostasis model assessment: insulin resistance and $\beta$-cell function from fasting plasma glucose and insulin concentrations in man. Diabetologia. 1985;28(7):412-9.

23. E. E, S. S, R. A. Effect and mechanism of herbal ingredients in improving diabetes mellitus complications. Jundishapur J Nat Pharm Prod. 2017;12(1). Available from: http://www.embase.com/search/results?subacti on=viewrecord\&from $=$ export\&id $=\mathrm{L} 617589946 \%$ 0Ahttp://dx.doi.org/10.5812/jjnpp.31657

24.Baynest HW. Classification, Pathophysiology, Diagnosis and Management of Diabetes Mellitus. J Diabetes Metab [Internet]. 2015;06(05). Available from: https://www.omicsonline.org/openaccess/classification-pathophysiologydiagnosis-and-management-ofdiabetesmellitus-2155-61561000541. php?aid=53137

25.Szkudelski T. The Mechanism of Alloxan and Streptozotocin Action in B Cells of the Rat Pancreas. Physiol Res 50. 2001;(50):536-46.

26. Eddouks M, Bidi A, El Bouhali B, Hajji L, Zeggwagh NA. Antidiabetic plants improving insulin sensitivity. J Pharm Pharmacol. 2014;66(9):1197-214.

27.Christodoulou M-I, Tchoumtchoua J, Skaltsounis A-L, Scorilas A, Halabalaki M.
Natural alkaloids intervening the insulin pathway: new hopes for anti-diabetic agents? Curr Med Chem [Internet]. 2018 Apr 30 [cited 2019 Jul 27];25. Available from: http://www.eurekaselect.com/161709/article

28.Schubert-Zsilavecz M. Screening of herbal extracts for activation of the human peroxisome proliferator-activated receptor. Pharmazie. 2006;61(11):952-6.

29.Lodgotra A, Verma P, Raj SS. Estimation of salivary and serum biomarkers in diabetic and non diabetic patients - A comparative study. J Clin Diagnostic Res. 2016;10(6):ZC56-61.

30.Jot E. Hypoglycemic Effect of Ethanol Leaf Extract of Thuamatococus Daneilli (ELETD) In Alloxan Induced Diabetic Wistar Rats. IOSR J Pharm Biol Sci. 2015;10(1):2319-7676. Available from: www.iosrjournals.org

31. Yadav R, Prakash Bhartiya J, Kumar Verma S, Kumar Nandkeoliar M. The evaluation of serum amylase in the patients of type 2 diabetes mellitus, with a possible correlation with the pancreatic functions. J Clin Diagnostic Res. 2013;7(7):1291-4.

32.Udia PM, Takem LP, Ufot UF, Antai AB, Owu DU. Insulin and alpha amylase levels in alloxaninduced diabetic rats and the effect of Rothmannia hispida ( K . Schum ) Fagerl leaf extract. J Phytopharm defects. 2016;5(1):1-5.

33.Patel R, Shervington A, Pariente JA, MartinezBurgos MA, Salido GM, Adeghate E, et al. Mechanism of exocrine pancreatic insufficiency in streptozotocin-induced type 1 diabetes mellitus. Ann N Y Acad Sci. 2006;1084:71-88.

34.Ahmed A, Wadud A, Jahan N, Bilal A, Hajera $S$. Efficacy of Adiantum capillus veneris Linn in chemically induced urolithiasis in rats. J Ethnopharmacol [Internet]. 2013;146(1):411-6. Available from: http://dx.doi.org/10.1016/j.jep.2013.01.011

35.Prowle JR, Kolic I, Purdell-Lewis J, Taylor R, Pearse RM, Kirwan CJ. Serum creatinine changes associated with critical illness and detection of persistent renal dysfunction after AKI. Clin J Am Soc Nephrol. 2014;9(6):101523. 